\title{
DUCH ŚWIĘTY W KONTEKŚCIE WSPÓŁCZESNEJ TEOLOGII KOMUNIJNEJ
}

Pneumatologia przeżyła swoje specyficzne odrodzenie dzięki obudzeniu się na nowo myśli komunijnej. Komunijna analiza relacji wewnątrztrynitarnych prowadzi do budowania modeli trynitarnych, które w nowy sposób próbują ukazać także miejsce i rolę Ducha Świętego w łonie Trójcy Świętej. Należą do nich również komunikacyjne i komunijne modele Trójcy Świętej, ukazujące Ducha Świętego jako jednoczące i pośredniczące ,środowisko sensu” oraz „przestrzeń” nieskończonej miłości w Bogu, co ma także znaczenie dla całej teologii.

Pneumatologia przeżyła w nowszej historii teologii renesans związany z nowym obudzeniem się kościelnego poczucia zjednoczenia na sposób „my”. Heribert Mühlen np. określa Ducha Świętego wewnątrztrynitarnie jako boskie „My”, zażyłą więź Ojca i Syna ,w Osobie”, „My w Osobie”. Analogicznie do tego wewnątrztrynitarnego określenia Ducha Świętego Mühlen wyjaśnia także Jego funkcję historiozbawczą; jest On jakby boskim ,byciem-poza-sobą”, poniekąd samym Bogiem, jakby „wychodzącym z siebie - Duchem Świętym pojętym jako boskie samooddawanie się"1. W takich wypowiedziach zawarty jest spory teologiczny potencjał komunikacyjny i komunijny. Dorobek trynitologii dostarcza bogatej re-

Ks. prof. dr hab. Marek Jagodziński - teolog dogmatyk, prof. nadzw. w Katedrze Teologii Prawosławnej w Sekcji Ekumenicznej na Wydziale Teologii KUL, wykłada w WSD w Radomiu; specjalizuje się w teologii komunikacji i komunii; e-mail: ksemjot@tlen.pl; ORCID: 00000002-6957-1034.

1 Por. B. Stubenrauch, Pneumatologia - traktat o Duchu Świętym, Kraków 1999, s. 215n; R. Laurentin, Nieznany Duch Święty. Odkrywanie Jego doświadczenia i Jego Osoby, thum. M. Tarnowska, Kraków 1998, s. 360-362; Y. Congar, Wierzę w Ducha Świętego. Duch Święty w ekonomii Objawienia i doświadczenie Ducha, thum A. Paygert, t. 1, Warszawa 1995, s. 64-67; K. Guzowski, Duch dialogujący. To dialegomenon Pneuma. Zarys pneumatologii dialogalnej, Lublin 2016, s. 389-392. 
fleksji systemowej, która organizuje się w ramach tradycyjnych i nowo powstających modeli teologicznych. Warto więc poświęcić więcej uwagi wspomnianemu potencjałowi komunikacyjno-komunijnemu, który pozwolił na wypracowanie nowszych i nośnych ujęć specyfiki Ducha Świętego w kontekście teologii Trójcy Świętej.

\section{KOMUNIJNAANALIZARELACJI WEWNĄTRZTRYNITARNYCH}

Trójca Święta jest Komunią Osób Boskich, w której nieustannie dokonuje się komunikacja miłości. Duch Święty jako Dar pochodzi od Ojca, podczas gdy Ojciec przekazuje Synowi wszystko, co sam ,posiada” - siebie samego w miłości. Bogactwem Boga jest właśnie Duch Święty, który wypływa z doskonałego oddania się Ojca, który nic nie zatrzymuje dla siebie - jako „Ojciec” ofiaruje siebie Synowi i pozostaje „Ojcem”. Również Syn, któremu wszystko zostało przekazane od Ojca, bez reszty ofiarowuje się Ojcu. Duch Święty jest więc Darem nie jak Ojciec i Syn, będący dla siebie nawzajem zarazem Dawcą i Darem, lecz jest czystym Darem, zamieszkującym całkowicie w Ojcu i całkowicie w Synu oraz umożliwiającym zaistnienie relacji między Nimi, a także odróżniającym Ich od siebie. Jest

Tezy H. Mühlena K. Guzowski przedstawia następująco: „w Trójcy Duch Święty jest jedną osobą w dwu osobach [...] podejmuje problem od strony analizy funkcjonowania gramatycznego i antropologicznego zaimków osobowych w naszych paradygmatach słownych: Ja-ty-on i My-wy. Relacja między Ojcem i Synem jest relacją Ja-ty lub mnie-tobie, na przykład tak jest w J 17,21-26. Nie można scharakteryzować relacji Ojca i Syna z Duchem Świętym jako relacji my-ty i odpowiednio: relacji Ducha w odniesieniu do Ojca i Syna jako relacji Ja-wy. Duch Święty jawi się jako My osobowe między Ja Ojca a Ty Syna jako ten, który ich łączy w My. $\mathrm{Z}$ analizy biblijnej Mühlen wyciąga wnioski: Ojciec i Syn jawią się jako dwa Ja, które utrzymują między sobą relację Ja-Ty. Świadomy kontekstu trynitarnego swego wywodu, Mühlen podkreśla, że Ojciec jest fundamentalnym Ja wewnątrztrynitarnym, natomiast Syn fundamentalnym Ty wewnątrztrynitarnym. Gdy Jezus wypowiada My, to ma to podwójny wymiar: włącza Ojca, ale nigdy ludzi; obejmuje Ojca i Ducha Świętego (por. J 14,23). Ta analiza językowa ma głęboki walor poznawczy i teologiczny, gdyż My obejmujące Ducha Świętego wskazuje na Niego jako Osobę dialogiczną. Również w naszej mowie My jest najbardziej podstawowym sposobem wskazywania na osobę. W świetle tego Duch Święty byłby My wewnątrztrynitarnym. To twierdzenie jest oparte na zachodniej nauce o pochodzeniu Ducha Świętego, podkreślającej, że w Trójcy mamy duo spirantes sed unus spirator - mowa tu o tchnieniu aktywnym. Działanie Ojca i Syna jest w każdym razie subsystentnym aktem My, gdyż dokonanym przez dwie osoby. Wyrazem tego aktu od strony tchnienia pasywnego jest Duch Święty, który jako osobowy Akt-My subsystuje między Ojcem i Synem. Konsekwencją relacji Ducha z Ojcem i Synem jest relacja Ja-Wy. Duch Święty jest nexus Ojca i Syna. Daje to obraz dwóch form perychorezy wewnątrz Trójcy Świętej: jednej zachodzącej między Ojcem i Synem w postaci Ja-Ty, a drugiej zachodzącej między Ojcem i Synem a Duchem Świętym. Dlatego jest On jedną Osobą w dwóch Osobach" (tamże, s. 390n). Por. M. Jagodziński, Komunijno-trynitarna pozycja Ducha Świętego..., s. 11. 
również Darem sprawiającym w niepowtarzalny i niezastępowalny sposób boskie bycie Bogiem, a przez to umożliwiającym komunikację wewnątrzboską i na zewnątrz. Realizuje się w tym prawdziwa komunia, która sprawia jedność i jednocześnie strzeże odrębności: Skoro Ojciec całkowicie ofiaruje się Synowi, a Syn czyni to samo w odniesieniu do Ojca, i Obaj w tej relacji nie zatracają się wzajemnie - ponieważ jako podmioty pozostają dla siebie nawzajem Dawcami - czysty Dar nie może być jedynie reprodukcją Ojca i Syna, stanowi raczej „coś” Innego, coś „Trzeciego”. On jest Bogiem-Duchem Świętym, który jako Osoba jednoczy w sobie Ojca i Syna, ale jako podmiot jest zarazem tym Darem - i oprócz tego odróżnia się od Ojca i Syna².

Fenomenologia tej doskonałej komunii ukazuje, że Ojciec jest miłością obdarowującą, Syn jest odbierającym i obdarowującym miłością, Duch Święty jest czystą miłością odbierającą ${ }^{3}$ ale są Oni tą samą miłością w trzech rytmach ${ }^{4}$. Duch Święty jest w tej „rytmice miłości” z jednej strony czystym otrzymywaniem, ponieważ jest darem Ojca i Syna (w inny sposób) oraz miłosną odpowiedzią w chwale i uwielbieniu, z drugiej zaś strony jest węzłem miłości między Ojcem i Synem, który sprawia Ich jedność i jedność bycia.

Jest „Trzecim” (według Ryszarda od św. Wiktora), który łączy w ogniu pozbawionej siebie miłości niepojęte bycie innym Ojca i Syna jako Ich ,jedność w przeciwstawieniu” jako „uprzedmiotowienie ich podmiotowości”, przez co występuje przeciwko możliwości Ich stopienia lub rozejścia się oraz nakierowuje Ich na siebie wzajemnie. Tak Duch Święty przez to, że jest darem Ojca dla Syna i Syna dla Ojca oraz potwierdza w ten sposób tożsamość dających - tożsamość w różnicy Ojca i Syna, a przez to tożsamość w różnicy boskiej Komunii miłości. W podwójnym charakterze węzła miłości Ojca i Syna oraz owocu tej miłości jako Trzeci gwarant tej miłości, Duch Święty nie jest jednak żadną dualnością. Ten podwójny charakter to dwa aspekty tej samej treści, w której wyraża boskie «My» miłości. Duch Święty jest Osobą, w której Komunia boskiej miłości znajduje pełny kształt, a nawet więcej - w niej w wyjściu „ponad siebie” dokonuje się „rozerwanie” Ojca i Syna. W nim uchwytna się staje osobowa całość boskiego życia ${ }^{5}$.

2 Por. B. Stubenrauch, Pneumatologia ..., s. 227n; R. Laurentin Nieznany Duch Święty, s. 378-385; M. Jagodziński, Komunijno-trynitarna pozycja Ducha Świętego..., s. 11n.

3 Por. G. Greshake, Trójjedyny Bóg. Teologia trynitarna, thum. J. Tyrawa, Wrocław 2009, s. 184n.

4 Por. R. Laurentin, Nieznany Duch Święty..., s. 377n.

5 M. Jagodziński, Trialogiczno-komunijna koncepcja trynitologii, Studia Diecezji Radomskiej 10 (2010/2011), s. 70; por. G. Greshake, Trójjedyny Bóg..., s. 185n; tenże, Wierzę w Boga trójjedynego. Klucz do zrozumienia Trójcy Świętej, Kraków 2001, s. 35; M. Jagodziński, Komunijno-trynitarna pozycja Ducha Świętego..., s. 12n. 
Bardzo specyficznie postrzega tę Komunię Hans Urs von Balthasar, według którego wzajemna wymiana istoty pomiędzy Ojcem i Synem prowadzi do dynamicznego zjednoczenia w Duchu Świętym, u korzeni którego leży kenotyczne oddanie siebie. Istotą miłości Ojca i Syna jest Ich wzajemne „zderzanie z sobą” w Duchu Świętym, w którym uwiecznia się konkretyzacja Bożej istoty. On sprawia wytrwałą „wymianę" wzajemnego bycia w sobie Ojca i Syna. Dynamika Bożej miłości wyraża się w tym, że istota Boża posiada w odniesieniu do każdej Osoby właściwość „,coraz więcej”. Osoba Ducha Świętego przyczynia się do nieograniczonego przenikania się Osób w Bogu. On jest źródłem energii wzajemnego obdarowywania się Ojca i Syna, uosobieniem Ich wzajemnego oddania się. Dramat dystansu pomiędzy Ojcem i Synem znajduje swoje rozwiązanie w Duchu Świętym. W paradoksalnym języku Adrienny von Speyr, Balthasar twierdzi, że w Trzeciej Osobie Bożej absolutne rozróżnienie między Ojcem i Synem staje się coraz większą miłością. Tchnienie Ducha jest płodnym spotkaniem darowującej się i przyjmującej miłości, która jakby opuszcza siebie samą, by we wspólnym tchnieniu miłości wydać Ducha miłoścí.

Balthasar podkreśla, że w istotowym zjednoczeniu Ojca i Syna odbierają Oni swoją jedność ,jako hipostatyczną istotę miłości”. Duch Święty stanowi konkretną rzeczywistość, stając się ,podmiotowym wcieleniem wzajemnej miłości Ojca i Syna”, czymś więcej niż tylko „wzajemnym nachyleniem” Ojca i Syna, owocem Ich miłości - jest Darem. To On sprawia czyn miłości Ojca oddającego całą swoją istotę Synowi, nie zostając w niczym umniejszony i pozostając także pierwszym, koniecznym aktem boskiego wyjścia „na zewnątrz”. Miłość Ojca i Syna zamyka się w Osobie Ducha Świętego w komunijną całość, „niestanowiącą zagrożenia dla ich osobowych właściwości” - tym bardziej że Duch nie pragnie być „kimś” dla siebie, lecz tylko czystym oznajmieniem miłości pomiędzy Ojcem i Synem?

W tym duchu Balthasar widzi Ducha Świętego jako najwyższą jedność Ojca i Syna oraz oddzielony od Nich, obiektywny, osobowy „owoc” Ich miłości, Ich odwiecznego rodzenia, „wynik” tej miłości i jej świadectwo. Trzecia Osoba Boska istnieje wiecznie jako samoistna płodność Bożej miłości, jedność niewythumaczalnej miłości Ojca i Syna. Istota Bożej miłości „narzuca” troistość w Bogu - tchnienie Ducha Świętego stanowi „proces” po Bożemu „konieczny”, ale absolutnie wolny: Duch Święty jest wyrazem jedynej w swoim rodzaju wolności Boga. Duch Boży jest tożsamy ze sobą i z istotą Boga - jest Bogiem i jako

\footnotetext{
Por. I. Bokwa, Trynitarno-chrystologiczna interpretacja eschatologii w ujęciu Hansa Ursa von Balthasara, Radom 1998, s. 105n; M. Jagodziński, Komunijno-trynitarna pozycja Ducha Świętego..., s. 13.

7 Por. I. Bokwa, Trynitarno-chrystologiczna interpretacja eschatologii..., s. 106; M. Jagodziński, Komunijno-trynitarna pozycja Ducha Świętego..., s. 13.
} 
Osoba jest „połączonym oddechem Ojca i Syna”. Relację pomiędzy Ojcem i Synem Balthasar opisuje jako bogactwo, podarunek, jedność, wspólnotę miłości. Duch Boży zawiera w sobie całą istotę Boga jako miłości, jest „miłością jako taką i absolutną”, wylaną całością bytu jako miłości. Duch miłości jest „,istotą Boga”, który jest jeden dzięki scalającej mocy Ducha miłości, ,jedności nieprzewyższalnej miłości”. Duch Święty stanowi „prosopon” Boskości, która w swej istocie jest czystym wydaniem siebie samej. Jest ,ukoronowaniem” narastającej Bożej miłości - „płodności miłości”. To w mocy Ducha Świętego Bóg „osiąga” nieustannie swoją ostateczną pełnię eschatologiczną ${ }^{8}$.

Prezentacja Boga jako miłości jednej i jedynej kryje w sobie obustronną analogię pomiędzy strukturą absolutnej miłości Boga a osobowym spotkaniem międzyludzkim. Oznacza to pojmowanie trynitarnej rzeczywistości Boga jako warunku umożliwiającego zaistnienie miłości między ludźmi, ale analogia ma też charakter pomocniczy, a głównym celem jest pojęciowo-obrazowe przybliżenie trynitarnej istoty Boga9 . Będąc miłością Ojca i Syna oraz więzią ich jedności, Duch Święty jest Ich wiekuistą komunikacją, a zatem Ich komunią ${ }^{10}$.

Duch jest komunią Miłującego i Umiłowanego, gwarantującym też komunię Miłującego ze swoimi stworzeniami i z dziejami ich cierpienia, nie z pominięciem Umiłowanego, ale właśnie w Nim i dzięki Niemu. [...] Zróżnicowanie Ojca i Syna zostało przyjęte w najwznioślejszej jedności miłości, pochodzącej od Ojca; a ta miłość, spoczywając na Synu i odbijając się w Nim, stale powraca do swego początku bez początku: Duch jest więzią wiecznej miłości. Dlatego Ojciec pozostaje początkiem, Syn przejawem, Duch Ich osobową więzią w ruchu Boskiej wieczności ${ }^{11}$.

Dzieje Syna i Ojca oraz krzyż są również dziejami Ducha Świętego, którego szczytowym aktem wydania jest żertwa ofiarna na krzyżu (J 19,30). Ukrzyżowany wydał Ojcu Ducha, którego Ojciec Mu dał, a którego w pełni otrzyma w dniu zmartwychwstania. W dniu wydania samego siebie przez Syna i Syna przez Ojca na śmierć Duch zostaje wydany przez Syna swemu Ojcu. Jest to go-

8 Por. I. Bokwa, Trynitarno-chrystologiczna interpretacja eschatologii..., s. 106n; M. Jagodziński, Komunijno-trynitarna pozycja Ducha Świętego..., s. 14.

9 Por. I. Bokwa Trynitarno-chrystologiczna interpretacja eschatologii..., s. 107.

10 Por. R. Laurentin, Nieznany Duch Święty..., s. 319n. K. Guzowski w zakończeniu swojego dzieła napisał, że zbiera ono „najlepsze intuicje tradycji teologicznej oraz refleksji personalistycznej, które pozwalają nam zobaczyć osobę Ducha Świętego w całej rozciągłości dynamiki osobowej i perychoretycznej, w komunijnej jedności i relacji, a także w podmiotowości relacyjnej i twórczej" (Duch dialogujący..., s. 425).

11 B. Forte, Istota chrześcijaństwa, tłum. K. Kozak, Lublin 2007, s. 99; M. Jagodziński, Komunijno-trynitarna pozycja Ducha Świętego..., s. 14. 
dzina „śmierci w Bogu”, opuszczenia Syna przez Ojca w Ich największej komunii miłości, wydarzenie, które dopełnia się w wydaniu Ducha Świętego Ojcu i umożliwia szczytowe wyjście Syna w inność świata. Bez wydania Ducha Świętego krzyż nie objawiłby się w całej swej głębi wydarzenia trynitarnego i zbawczego. Gdyby Duch nie pozwolił się „wydać” w ciszy śmierci, godzina ciemności mogłaby być źle zrozumiana - nie jako akt w Bogu, jako wydarzenie historii miłości nieśmiertelnego Boga. W godzinie krzyża także i Duch Święty tworzy historię w Bogu, ponieważ wydany Ojcu gwarantuje inność Syna od Niego w solidarności $\mathrm{z}$ grzesznikami, chociaż pozostając $\mathrm{w}$ nieskończonej komunii wyrażonej w ofiarnym posłuszeństwie Ukrzyżowanego. „Krzyż, jako historia Syna, Ojca i Ducha, jest trynitarną historią Boga"12.

Istotą Ojca jest osobowa agape. Jest ona Osobą w całym znaczeniu tego słowa, najważniejszą i jedyną w sobie samej i przez siebie samą, gdyż jest ofiarowywaniem siebie w Synu. Cała miłość znajduje się w Ojcu i przelewa się w Syna jako jedynego i absolutnie umiłowanego oraz miłującego wzajemnie, razem z Duchem Świętym - jako miłością jednocześnie otrzymywaną i oddawaną. Ta miłość jest w Ojcu, pierwszym i podstawowym Źródle miłości.

Nie można więc powiedzieć [...] że Duch Święty jest w Bogu miłością osobową, ponieważ miłość, będąca życiem Boga, która jest Ojcem w samym jego ojcostwie, która jest Synem jako umiłowanym i miłującym wzajemnie, dopełnia się w Duchu Ojca, będącym właśnie Duchem przybrania za Synów, spoczywającym na Synu jako Duch dobrowolnej wzajemności, przez którego ten sam jest zarazem w najwyższym stopniu miłujący i miłowany. W tym znaczeniu Duch, jak wskazuje jego nazwa, jest tchnieniem życia Bożego, lub inaczej - jest On jakby sercem Bóstwa, sercem Ojca, które jest jednocześnie sercem Syna, darem udzielającym życia, pozwalającym miłować miłością, jaką się jest miłowanym. Życie Boga jest zatem doskonałe w sobie samym jako życie miłości, [...] która [...] musi istnieć między dwiema Osobami, a która, pomiędzy tych dwóch stanowiących jedno - Ojca i Syna, nie mówimy, że wkracza jako trzecia Osoba, co byłoby największym nonsensem, ale - że jest pieczęcią ich jedynej bliskości i niewyczerpanym źródłem ich nieskończoności. Dlatego ów Duch, w którym miłość Boża, miłość, która jest Bogiem, objawia się w swej doskonałości, w swej świętości ponad wszelkimi definicjami $[\ldots]^{13}$.

12 B. Forte, Istota chrześcijaństwa..., s. 70n; M. Jagodziński, Komunijno-trynitarna pozycja Ducha Świętego..., s. 15.

13 L. Bouyer, Duch Święty Pocieszyciel. Duch Święty $i$ życie $w$ tasce, thum. A. Liduchowska, Kraków 2000, s. 535n. Autor uzupełnia tę wypowiedź myślą o kenozie Ducha Świętego, w której On objawia się także stworzeniu (por. tamże, s. 545n); por. R. Laurentin, Nieznany Duch Święty..., s. 369-373; M. Jagodziński, Komunijno-trynitarna pozycja Ducha Świętego..., s. 6n. 
Zaprezentowane ujęcia komunikacyjno-komunijnej rzeczywistości Ducha Świętego zachęcają do ciągle na nowo podejmowanych prób systematyzacji teologicznej i ujmowania ich rezultatów w postaci nowych modeli trynitarnych, które zawierają w sobie także ważne akcenty pneumatologiczne.

\section{WSPÓŁCZESNE MODELE TRYNITARNE}

W ludzkim poszukiwaniu prawdy o Bogu ważną rolę spełniają teorie i modele trynitologiczne ${ }^{14}$. Według Ksawerego Pikazy modele to „struktury konceptualne, formy myślenia i usytuowania się wobec wielkiego misterium" ${ }^{15}$. W sensie szerszym model to schemat myślowy systematyzujący wiedzę i doświadczenie, a w sensie ściśle trynitologicznym ma on być narzędziem poglądowego przybliżenia się do misterium Trójcy Świętej ${ }^{16}$. W modelach trynitarnych istotny jest sposób mówienia o pochodzeniach trynitarnych, ale także zakres immanentny i ekonomiczny oraz język teologiczny: znaczenie terminów, rozumienie symboli, sposób tworzenia konstrukcji, zabarwienie kulturowe, religijne, filozoficzne i formacja teologiczna ${ }^{17}$.

Wśród trynitarnych modeli dwudziestowiecznych Piotr Liszka wymienia modele Karla Bartha i Karla Rahnera ${ }^{18}$, Brunona Fortego i dopełniające je modele Leonarda Boffa ${ }^{19}$, Ksawerego Zubiriego ${ }^{20}$ oraz modele eksplikacyjne, wyróżnione przez Czesława Stanisława Bartnika ${ }^{21}$. Bernd Jochen Hilberath nazywa analogię psychologiczną (model psychologiczny) analogią intrapersonalną (wewnątrzosobową), a drugą analogię (biblijno-grecką) - analogią interpersonalną (międzyosobową). Ukazuje przy tym braki każdej z nich ${ }^{22}$ i próbuje naszkico-

14 Por. S. Kołata, Komplementarność modeli w teologii trynitarnej, Kraków 2017, s. 32-38.

15 X. Pikaza, Dios como Espíritu y Persona. Razón humana e Misterio Trinitario, Salamanca 1989, s. 112, cyt. za: P. Liszka, Duch Święty, który od Ojca (i Syna) pochodzi, Wrocław 2000, s. 193.

16 Por. S. Kołata, Komplementarność modeli..., s. 11. „Jest to pojęcie bardzo złożone i pod wieloma względami pokrewne z symbolem, analogią, czy nawet naukowym paradygmatem. Po wtóre, trzeba ocenić przydatność modelu jako narzędzia metodologicznego nie tyle do opisu «Boga w relacji do», ale przede wszystkim do opisu wewnętrznego życia Trójcy Świętej” (tamże, s. 14); por. tamże, s. 23-38.

17 Por. P. Liszka, Duch Święty..., s. 194.

18 Por. tamże, s. 243-245.

19 Por. tamże, s. 245n.

20 Por. tamże, s. 246-248.

21 Por. tamże, s. 248-251.

22 Por. B.J. Hilberath, Pneumatologie, w: Handbuch der Dogmatik, red. T. Schneider, t. 1, Düsseldorf 2000, s. 532. S. Kołata przedstawia w swojej książce Komplementarność modeli... (s. 38-44) ogólny zarys typologii modeli Boga. 
wać model integrujący obydwa poprzednie, w którym Duch Święty występuje jako wewnątrztrynitarna „,przestrzeń”, „medium”, „wydarzenie” pośredniczenia. Otwiera to możliwość komunikacyjnego ujęcia Osób trynitarnych jako będących w relacji ${ }^{23}$. Markus Knapp podjął kwestię zastosowania teorii komunikacyjnego działania jako modelu myślowego pomagającego wyjaśnić pojęcie Trójjedynego Boga $^{24}$, a później poszerzył to spojrzenie o perspektywę działania Boga i skutków tego działania ${ }^{25}$.

W literaturze teologicznej bardzo pozytywnie oceniany jest komunijny model trynitarny autorstwa Gisberta Greshakego, dla którego trójjedyność jest najwyższą formą jedności. Jedność i troistość nie są w Trójcy Świętej przeciwstawne ani podporządkowane sobie, co najwyraźniej uwidacznia się w wydarzeniu wzajemnego daru Ojca, Syna i Ducha Świętego. W tym wydarzeniu wyraźniejsza staje się tożsamość każdej z Osób, a ponadto ukazuje się ona jako relacja i wzajemność. W perychorezie trynitarnej bowiem jedność w Trójcy Świętej nie może być rozpatrywana esencjalistycznie, jako coś istniejącego przed Osobami, lub interpersonalnie, jako coś następującego po nich, gdyż dokonuje się właśnie w tej perychorezie i przez tę perychorezę ${ }^{26}$. Pojęcie perychorezy służy więc temu, żeby komunię (communio) rozumieć jako komunikację (communicatio) ${ }^{27}$.

Greshake uważa, że pierwotna koncepcja perychorezy zawierała w sobie przekonanie, iż w każdej Osobie obecne są odniesienia do pozostałych Osób i dlatego

23 Por. B.J. Hilberath, Pneumatologie..., s. 534-536, 538n. S. Kołata w swojej monografii poświęconej komplementarności modeli w teologii trynitarnej nawet nie wymienia modelu komunikacyjnego, chociaż dotyczy ona komplementarności między modelami przyrodniczymi a teologią. „Kwestię modeli w nauce w niezwykle wnikliwy sposób przedstawia w swoim klasycznym opracowaniu I.G. Barbour. Twierdzi on, że model jest symbolicznym przedstawieniem, w określonym celu, wybranych aspektów zachowania jakiegoś złożonego systemu. Stanowi on narzędzie wyobraźni, służące bardziej do organizowania doświadczenia niż do opisywania świata. Do tak sformułowanej definicji nawiązuje również J. Kłoczowski, zauważając w teorii modelu potencjał rozwojowy nauki. Rozwój następuje w ten sposób, że buduje się jakiś model badanej rzeczywistości, a następnie weryfikuje jego prawdziwość. Modele nie tylko opisują doświadczenie, ale ich użycie pozwala dobrze wydobyć problematykę do dalszego przebadania. Modele mają więc także zastosowanie heurystyczne" (S. Kołata, Komplementarność modeli..., s. 20). Zob. I.G. Barbour, Mity. Modele. Paradygmaty, thum. M. Krośniak, Kraków 1984; T. Dola, Podstawy zastosowania pojęcia model w teologii, w: Czas. Ewolucja. Duch, thum. K. Wolsza, Opole 1997, s. 382-391.

24 Por. M. Knapp, Die Theorie des kommunikativen Handelns als Denkmodell für den trinitarischen Gottesbegriff?, w: Communio Sanctorum. Einheit der Christen - Einheit der Kirche, red. J. Schreiner, K. Wittstadt, Würzburg 1988, s. 323-337.

25 Por. M. Knapp, Trinitätslehre und Handlungstheorie, w: Gottesrede - Glaubenspraxis. Perspektiven theologischer Handlungstheorie, red. E. Arens, Darmstadt 1994, s. 49-68.

26 Por. G. Greshake, Trójjedyny Bóg..., s. 82n.

27 Por. K. Guzowski, Duch dialogujacy..., s. 381n. 
Sobór Florencki nauczał, że dzięki tej jedności Ojciec cały jest w Synu, Syn cały w Ojcu i cały w Duchu Świętym, Duch Święty zaś cały w Ojcu i cały w Synu. Samo związanie jedności z naturą (istotą) miało przy tym podłoże filozoficzne, gdyż ,jedna natura” Boga oznacza komunię miłości między Osobami. Zgodnie $\mathrm{z}$ tym biblijna formuła „Bóg jest Miłością” (1 J 4,8.16) wyraża najwyższą formę jedności, a nie tylko przedmiotową dobroć ${ }^{28}$.

\section{MIEJSCE DUCHA ŚWIĘTEGO W KOMUNIKACYJNYM MODE- LU TRÓJCY ŚWIĘTEJ}

Trynitarna rzeczywistość Ducha Świętego może być pojmowana w kategoriach relacyjnych jako jedność, uosobione Unio i Communio jednocześnie udzielającej się i przyjmowanej miłości w Bogu. Duch Święty stanowi wewnątrztrynitarne, odwieczne i pośredniczące „medium”, „przestrzeń” wzajemnej miłości Ojca i Syna. Bóg jest „Duchem” - Duchem miłości Ojca i Syna, i tylko w tym wspólnym Duchu, będącym zarazem „przestrzenią" i „matczynym łonem” (Y. Congar) miłości Boga. Duch Święty jednocześnie wyrasta z tego wzajemnego oddania jako jego „rezultat” („który od Ojca i Syna pochodzi”). W Nim wzajemne odniesienie (oddanie) miłości między Ojcem i Synem znajduje inną od nich, obejmującą, łączącą i przekraczającą „formę” jedności; przyjmuje kształt „My”, które przy całej zależności od Ojca i Syna zachowuje przekraczającą ich relatywną samoistność („który z Ojcem i Synem wspólnie odbiera uwielbienie i chwałę"). Dlatego też Tradycja Kościoła określa specyficznie osobowy charakter Ducha Świętego słowem „Dar” - wzajemne oddanie Ojca i Syna kulminują

${ }_{28}$ Por. tamże, s. 382. „W tej optyce dynamiki Boskiej communio można też łatwiej zrozumieć, dlaczego Bóg ekstatycznie, wychylając się poza siebie, ku stworzeniu, do tego dialogu miłości zaprasza i włącza również osoby ludzkie, będące adresatami samoudzielającego się Boga" (tamże, s. 383); por. tamże, s. 383-386. „Propozycja Greshakego jest o tyle interesująca, że pragnie przełamać neoplatoński schemat o pochodzeniu Osób. Określając w Boskiej communio każdą z Osób jako Dar dający siebie i przyjmujący w siebie, odsuwa on schemat genetyczny, a zastępuje go schematem wzajemności w perychorezie darów. Mimo iż Ojciec jest nazwany Pra-darem, to jednak nie może być pomyślany w izolacji od innych Osób, skoro tajemnica miłości jest tajemnicą Osób, które są dla siebie darem. W wewnątrzboskim obdarowaniu nie ma ani utraty, ani wzrostu. Pomimo wielu walorów ta propozycja jednak w niektórych miejscach naśladuje schemat pochodzeń, gdy Greshake określa Ojca jako «Pra-podstawę» innych Osób, Syna jako «przyjęcie, Ducha jako «czyste przyjmowanie». Mimo wszystko w tym schemacie communio Ojciec jest widziany jako Centrum, a nie jako początek pochodzeń. Ponadto Greshake czerpie z trynitologii inspirację do swej trialogiczej koncepcji osoby ludzkiej, bo osoba ludzka jest refleksem Komunii Trynitarnej i w ten sposób pełni funkcję locus theologicus" (tamże, s. 388n). 
w Nim, „konkretyzują się” i przyjmują postać wzajemnie darowanej wspólnoty i radości. Trójjedyny Bóg ofiarowuje siebie stworzeniu, przychodząc do niego jako ten „Dar”, jako Moc Ducha Świętego, aby zapoczątkować wspólnotę z Bogiem i ze wszystkimi ludźmi. To wydarzenie przyjętego „Daru Bożego” nazywamy „Kościołem”. Trynitarny kontekst cechuje jeszcze jeden aspekt Ducha Świętego jako jednoczącej miłości Boga: Ojciec i Syn jako bieguny wzajemnego odniesienia nie nakładają się w Nim na siebie, lecz wprost przeciwnie, ukazują swoją niezamienną, osobową różność. Ten fakt stworzył podstawę zachodniego rozumienia osoby, wolności, miłości i jedności - im głębsza jest jedność między kochającymi się osobami, tym większa jest gwarancja wolności bycia innym. Pierwotny model trynitarny tego pozornego paradoksu umożliwia zachowanie - w najściślejszym komunikowaniu wzajemnym - jednocześnie najwyższego zróżnicowania osobowego, a ta prawidłowość jest przecież podstawą kapitalnego znaczenia pneumatologii w eklezjologii ${ }^{29}$. Pod względem poznawczym Duch Święty dostępny jest tylko poprzez historycznego i wywyższonego Jezusa. Z drugiej strony jest On równocześnie „transcendentalnym” warunkiem umożliwiającym wiarę w Jezusa Chrystusa - stąd chrystologia wymaga pneumatologii jako warunku swojego istnienia (Duch Święty jest „przestrzenią” wiary) ${ }^{30}$.

W takim kontekście trynitarnym dla wyjaśnienia jedności i zróżnicowania trynitarnej „struktury odniesien” Medard Kehl posługuje się schematem zaczerpniętym z modelu komunikatywnego działania: „Ojciec” jest podmiotem i źródłem („Skąd”) nieskończenie ofiarującej się miłości, „Syn” jest pochodzącym od Ojca celem i partnerem („Dokąd”) nieskończenie otrzymywanej miłości. „Duch Święty” jest jednoczącym i pośredniczącym środowiskiem („W czym”) tej nieskończonej miłości. Miłość sama wreszcie jest treścią, zawartością („Co”) tego, co istnieje między Ojcem, Synem i Duchem Świętym, i jest identyczna z Boską ,istotą" 31 .

29 Por. M. Kehl, Die Kirche. Eine katholische Ekklesiologie, Würzburg 1994³ , s. 68-73; M. Jagodziński, Trynitarne podstawy Kościoła jako komunii, Studia Theologica Varsaviensia 42,1 (2004), s. 59n; tenże, Teoria komunikacyjnego działania w nauce o Trójcy Świętej, Studia Koszalińsko-Kołobrzeskie 15 (2010), s. 60n; H. Wagner, Dogmatyka, tłum. J. Zychowicz, Kraków 2007, s. 81.

30 Por. M. Kehl, Die Kirche..., s. 68-70; M. Jagodziński, Teoria komunikacyjnego działania w nauce o Trójcy Świętej..., s. 61n.

31 Por. M. Kehl, Kirche als Institution - eine theologische Begründung, w: M. Kehl, N. Glatzel, N. Mette, Kirche als Institution, Studienbrief II/1, Tübingen 1984, s. 121; M. Jagodziński, Communio dzięki komunikacji. Teologiczny wymiar teorii komunikatywnego dziatania w eklezjologii Medarda Kehla SJ, Radom 2002, s. 343; tenże, Komunijna wizja Kościoła wedtug Medarda Kehla SJ, Kraków 2009, s. 17; tenże, Teoria komunikacyjnego dziatania w nauce o Trójcy Świętej..., s. 63. 
Tradycja nazywała często Ducha Świętego „Jednością” (unio) lub „Wspólnotą" (communio) w Bogu ${ }^{32}$. Ponieważ wspólnota między Ojcem i Synem jest relatywnie samodzielnym (jako Osoba) istnieniem Bożej Miłości - Duch Święty stanowi „My” w Bogu ${ }^{33}$. Boskiej Wspólnocie między Ojcem i Synem (równej Duchowi Świętemu) przysługuje w sposób pierwotny i wzorczy właściwość pośredniczącego „W czym”, ponieważ Bóg sam w sobie, w Duchu Świętym, jest wydarzeniem pośredniczenia. $Z$ jednej strony jedność między Ojcem i Synem jest zawsze istniejącą uprzednio wspólną „Przestrzenią” (Duchem) ich odniesienia, z drugiej jednak strony wspólny Duch ustanawiany jest tylko dzięki wzajemnemu odniesieniu Ojca i Syna i bez tego odniesienia nie byłoby „My” wspólnoty. Duch Święty nie wchodzi jednak w te dwa „bieguny” i ich wzajemne odniesienie, lecz tworzy własny, odrębny sposób boskiej miłości. Jeśli człowiek pozwoli na objęcie się tym wzajemnym odniesieniem Ojca i Syna - zostaje przyjęty „w” Ducha Świętego, do tej Wspólnoty: dlatego Biblia mówi o darze Ducha Świętego jako o „otrzymaniu Ducha Świętego” i „byciu napełnionym przez Ducha Świętego” ${ }^{\text {"34. }}$

Ponieważ Duch Święty jest pośredniczącą „wspólnotą” między Ojcem i Synem, przyjęcie do niej dokonuje się na podstawie wspólnoty i jest wspólnototwórcze. Duch Święty jako Komunia w Bogu jest właściwym, teologicznym fundamentem komunii kościelnej i właśnie dzięki temu zasadniczo różni się ona od innych wspólnot. Uprzedni dar wspólnej „przestrzeni życia” wiary nie opiera się więc na ludzkiej woli wspólnoty, lecz na darze Ducha Świętego, na podarowaniu udziału we wspólnocie, która istnieje w Bogu, a Kościół staje się historycznym znakiem wewnątrzboskiej Komunii - „sakramentem Ducha Świętego" 35 .

Duch Święty jest pośredniczącym „w czym” historii zbawienia, pośredniczącą mocą, w której i przez którą Jezus Chrystus przychodzi wewnętrznie do człowieka. Pośredniczy jako udzielone uprzednio i na stałe, a jednocześnie dawane za każdym razem, łączące podmiot i przedmiot, „środowisko sensu” ${ }^{\text {"36 }}$. On jest „środowiskiem sensu” wzajemnej miłości Ojca i Syna oraz Ich ujawniającą się w Nim i łączącą Ich „formą społeczną" ${ }^{37}$. Przez Niego historia ludzkości zostaje włączona w wydarzenie tej miłości po to, by stała się doskonałą, historyczną

\footnotetext{
Por. M. Kehl, Die Kirche..., s. 70-73.

Por. M. Kehl, Kirche als Institution - eine theologische Begründung..., s. 136.

34 Por. tamże, s. 122; tenże Kirche - Sakrament des Geistes, w: Gegenwart des Geistes. Aspekte der Pneumatologie, red. W. Kasper, Freiburg 1979, s. 158n; M. Jagodziński, Trynitarne podstawy Kościoła, Studia Theologica Varsaviensia 42,1 (2004), s. 61.

35 Por. M. Kehl, Kirche - Sakrament des Geistes..., s. 155-161; tenże, Kirche als Institution, w: Handbuch der Fundamentaltheologie 3, Traktat: Kirche, red. W. Kern, H.J. Pottmeyer, M. Seckler, Tübingen-Basel 2000, s. 140n; M. Jagodziński, Trynitarne podstawy Kościoła ..., s. 61n.

36 Por. M. Kehl, Kirche-Sakrament des Geistes..., s. 157.

37 Por. tamże, s. 159.
} 
postacią tożsamej z Nim komunii - „społecznej formy“ miłości Boga. Ta pośrednicząca moc Ducha Świętego znajduje swój cel w rozszerzeniu miłości Ojca i Syna na powszechną komunię ludzi z Bogiem i między ludźmi ${ }^{38}$.

\section{PODSUMOWANIE}

Analiza tradycji teologicznej i nowszych interpretacji dotyczących Trójcy Świętej pozwala dostrzec komunikacyjno-komunijne wymiary jej rzeczywistości oraz wyeksponować taką samą pozycję Ducha Świętego. Systematyczne ujęcia teologiczne pozwalają z kolei na konstruowanie coraz to nowszych modeli trynitarnych, spośród których współczesna teologia zwraca szczególną uwagę na komunijny model trynitarny autorstwa G. Greshakego, a warto także uwzględnić komunijno-komunikacyjny model trynitarny wypracowany przez M. Kehla. Pozwalają one zintegrować dotychczasowy dorobek pneumatologii i jej nowsze dokonania przy użyciu nośnych teologicznie kategorii komunikacji i komunii oraz ukazywać Ducha Świętego jako wewnątrztrynitarne „medium”, „przestrzeń”, „W czym”, pośredniczące ,środowisko sensu”, „społeczną formę” wzajemnej miłości Ojca i Syna, a za pomocą pojęcia perychorezy Komunię rozumieć jako komunikację. Takie zaś pojmowanie Ducha Świętego ma również doniosłe konsekwencje dla eklezjologii i antropologii.

\section{BIBLIOGRAFIA}

Barbour I.G., Mity. Modele. Paradygmaty, tłum. M. Krośniak, Kraków 1984.

Bokwa I., Trynitarno-chrystologiczna interpretacja eschatologii w ujęciu Hansa Ursa von Balthasara, Radom 1998.

Bouyer L., Duch Święty Pocieszyciel. Duch Święty i życie w tasce, thum. A. Liduchowska, Kraków 2000.

Bouyer L., Ojciec niewidzialny. Drogi do tajemnicy Boga, tłum. J, Brzozowski, G. Jędrzejowska, W. Szymona, Kraków 2000.

Congar Y., Wierzę w Ducha Świętego. Duch Święty w ekonomii Objawienia i doświadczenie Ducha, thum A. Paygert, t. 1, Warszawa 1995.

Dola T., Podstawy zastosowania pojęcia model w teologii, w: Czas. Ewolucja. Duch, thum. K. Wolsza, Opole 1997, s. 382-391.

Forte B., Istota chrześcijaństwa, thum. K. Kozak, Lublin 2007.

38 Por. tamże, s. 159n; tenże, Kirche als Institution..., s. 190; M. Jagodziński, Trynitarne podstawy Kościoła..., s. 62; tenże, Teoria komunikacyjnego działania w nauce o Trójcy Świętej..., s. 62-64. 
Greshake G., Wierzę w Boga trójjedynego. Klucz do zrozumienia Trójcy Świętej, Kraków 2001.

Greshake G., Trójjedyny Bóg. Teologia trynitarna, tłum. J. Tyrawa, Wrocław 2009.

Guzowski K., Duch dialogujacy. To dialegomenon Pneuma. Zarys pneumatologii dialogalnej, Lublin 2016.

Hilberath B.J., Pneumatologie, w: Handbuch der Dogmatik, red. T. Schneider, t. 1, Düsseldorf 2000, s. 445-552.

Jagodziński M., Communio dzięki komunikacji. Teologiczny wymiar teorii komunikatywnego działania w eklezjologii Medarda Kehla SJ, Radom 2002.

Jagodziński M., Trynitarne podstawy Kościoła jako komunii, Studia Theologica Varsaviensia 42,1 (2004), s. 51-79.

Jagodziński M., Komunijna wizja Kościoła wedtug Medarda Kehla SJ, Kraków 2009.

Jagodziński M., Teoria komunikacyjnego działania w nauce o Trójcy Świętej, Studia Koszalińsko-Kołobrzeskie 15 (2010), s. 47-69.

Jagodziński M., Trialogiczno-komunijna koncepcja trynitologii, Studia Diecezji Radomskiej 10 (2010/2011), s. 59-72.

Jagodziński M., Komunijno-trynitarna pozycja Ducha Świętego, Roczniki Teologiczne 66,7 (2019), s. 5-16.

Kehl M., Kirche - Sakrament des Geistes, w: Gegenwart des Geistes. Aspekte der Pneumatologie, red. W. Kasper, Freiburg 1979, s. 155-180.

Kehl M., Kirche als Institution - eine theologische Begründung, w: M. Kehl, N. Glatzel, N. Mette, Kirche als Institution, Studienbrief II/1, Tübingen 1984, s. 78-150.

Kehl M., Die Kirche. Eine katholische Ekklesiologie, Würzburg 1994³.

Kehl M., Kirche als Institution, w: Handbuch der Fundamentaltheologie 3, Traktat: Kirche, red. W. Kern, H.J. Pottmeyer, M. Seckler, Tübingen-Basel 2000, s. 129-145.

Knapp M., Die Theorie des kommunikativen Handelns als Denkmodell für den trinitarischen Gottesbegriff?, w: Communio Sanctorum. Einheit der Christen - Einheit der Kirche, red. J. Schreiner, K. Wittstadt, Würzburg 1988, s. 323-337.

Knapp M.,, Trinitätslehre und Handlungstheorie, w: Gottesrede - Glaubenspraxis. Perspektiven theologischer Handlungstheorie, red. E. Arens, Darmstadt 1994, s. 49-68.

Kołata S., Komplementarność modeli w teologii trynitarnej, Kraków 2017.

Laurentin R., Nieznany Duch Święty. Odkrywanie Jego doświadczenia i Jego Osoby, tłum.

M. Tarnowska, Kraków 1998.

Liszka P., Duch Święty, który od Ojca (i Syna) pochodzi, Wrocław 2000.

Pikaza X., Dios como Espíritu y Persona. Razón humana e Misterio Trinitario, Salamanca 1989.

Stubenrauch B., Pneumatologia - traktat o Duchu Świętym, Kraków 1999.

Szczurek J.D., Trójjedyny, Kraków $2003^{3}$.

Wagner H., Dogmatyka, tłum. J. Zychowicz, Kraków 2007. 
Słowa kluczowe: pneumatologia, relacje wewnątrztrynitarne, model trynitarny, komunikacja, komunia

THE HOLY SPIRIT IN THE CONTEXT OF MODERN COMMUNION THEOLOGY

\section{Summary}

Pneumatology survived its specific revival made possible by the awakening of communion thought again. The communion analysis of intra-Trinitarian relations leads to building Trinitarian models, which in a new way try to show the place and role of the Holy Spirit in the bosom of the Holy Trinity. They also include communicative and communion models of the Holy Trinity, showing the Holy Spirit as unifying and mediating "environment of meaning" and "space" of infinite love in God, which is also important for all theology.

Keywords: pneumatology, intra-Trinitarian relations, Trinitarian model, communication, communion 